\title{
Studying in the Superdiverse City: System_D and the Challenge of Solidarity in Brussels
}

\author{
Hans Schildermans ${ }^{1} \cdot$ Joke Vandenabeele ${ }^{2} \cdot$ Joris Vlieghe ${ }^{2} \cdot$ Piotr Zamojski $^{3}$
}

Published online: 12 March 2020

(c) The Author(s) 2020

\begin{abstract}
In recent years, the relation between studying and learning has been a topic of debate. This article is mainly interested in a concept of study practices, conceived of as practices that are strongly engaged with issues of living together in a superdiverse city. Such practices firstly require to think the relation between studying and learning in other-than-oppositional terms, and secondly, to raise questions concerning the political role of education. The aim of the article is double in that it wants to further elaborate the concept of study practices in relation to a concrete practice on the one hand, and, on the other, that it has the objective to rethink in educational terms the notion of solidarity-deeply entwined with matters of living together in superdiversity. These aims are pursued based on an analysis of the study practice of System_D, a film festival in the disadvantaged neighborhoods of Brussels, drawing on the work of Isabelle Stengers and Donna Haraway.
\end{abstract}

Keywords Study practices $\cdot$ Learning anew $\cdot$ Art education $\cdot$ Educational solidarity System_D

\section{Introduction}

Against the backdrop of a growing interest in the notion of study and studying (e.g. Ford 2016b; Lewis 2014; Moten and Harney 2013; Simons and Masschelein 2009), we explore in this article how study practices offer the possibility to think about issues of living

Hans Schildermans

hans.schildermans@univie.ac.at

Joke Vandenabeele

Joke.vandenabeele@kuleuven.be

Joris Vlieghe

Joris.vlieghe@kuleuven.be

Piotr Zamojski

pedpz@ug.edu.pl

1 Center for Foundations of Education, University of Vienna, Sensengasse 3A, 1090 Vienna, Austria

2 Laboratory for Education and Society, KU Leuven, Vesaliusstraat 2, 3000 Leuven, Belgium

3 Institute of Education, University of Gdansk, U1. Jana Bażyńskiego 4, 80-309 Gdańsk, Poland 
together in a global and superdiverse world (Cf. Schildermans et al. 2019a). In much recent philosophical literature, studying has been put forward as an addition or an alternative to the dominant discourse of learning which neglects, marginalizes or ignores both the political and collective aspects of educational practices (cf. Lewis 2015; Ruitenberg 2017). In this article, however, we do not want to make a sharp opposition between studying and learning, but we are interested in the way in which learning and studying are intertwined (Cf. Lewis 2015; Zhao 2019). More precisely, it is our contention that conceptualizing learning from the perspective of study practices, understood as an "occasion for politics" (cf. Ford 2017, p. 457), allows for understanding learning as a process of indeterminate, collective transformation.

In our view, it is important to stress at least two features that characterize study practices. First, although studying is often associated with a solitary activity - the scholar deep in thought over a manuscript in her study room (Cf. Lewis 2015) — we take it to be a collective endeavor: the issue that engages people to think also makes them come together and be a part of a shared enterprise. Second, studying implies a specific temporal logic, viz. slowing down (Mollenhauer 2013). Studying an issue comes with the temporary suspension of directly influencing social reality and its power structures; instead it offers the occasion for hesitation, and therefore for coming up with responses that are not immediately suggested by the situation studiers find themselves in.

Given our interest in issues of living together in a global and superdiverse world we choose to develop our conception of learning in relation to the concrete case study of System_D, a community-based arts project in Brussels which invites youngsters to shoot short movies about their lives and to show these during a public film screening and discussion. Drawing on the work of Stengers (2006, 2010, 2017) and Haraway (2016), we propose to conceive of this project as a practice of study. This means that we resist current interpretations of System_D as being either a project that fosters social cohesion among a multi-ethnic population, or as merely an occasion to acquire specific technical skills or to develop an artistic style. As a study practice, System_D addresses directly the question of how we can live together in a world that has become increasingly diversified, and as such it offers a very concrete enactment of what solidarity could mean in such a superdiverse world.

Overall, the answer to this question usually goes into one of following two directions: On the one hand, there is a strand of thought which we would call pessimistic: the many and almost unavoidable conflicts that are ubiquitous in the superdiverse society ${ }^{1}$ warrant a deep suspicion whether solidarity is still a feasible goal to attain (e.g. Cantle 2012; Putnam 2000). On the other hand, some hold a more optimistic view and claim that if solidarity is not a viable option today, it must become a purpose that can be realized through effective educational projects: we can and must learn how to strengthen community-bonds (e.g. European Commission 2018). In both cases solidarity is rendered as a problem: either as a castle in the air we need to deconstruct, or as a not-yet realized but urgently to accomplish educational goal.

\footnotetext{
1 The notion of superdiversity refers to the fact that in contemporary societies it no longer makes sense to conceptually make a difference between majority and minority groups. Hence, it denotes a particular challenge to living together, because it has become clear that old ideals such as integration, social cohesion, or multiculturalism have become obsolete in relation to the 'diversification of diversity' (cf. Vertovic 2007; Schuermans et al. 2017).
} 
In this article we refrain from taking the pessimists' path, but we also want to set a step beyond the optimistic position which conceives of solidarity as merely a learning objective. We propose that there exists a properly educational solidarity - a form of solidarity that is inherent to studying together when gathered around a problem that forces us to think - which is not identical with other (political, sociological, economic, etc.) forms of solidarity-e.g. the (freely or coerced) sharing and redistribution of scarce means, identification with the same values and norms or common struggle against oppression. Solidarity is what comes into being when people pay attention to the same issue at stake and start to think together beyond solutions that are already given in or predefined within the existing societal order. Here, they experience commonality, but also feel that they become able to respond to the situation they are in and that they can start again with each other and with the world, which we, reclaiming the notion of learning, would suggest to understand as learning anew.

\section{The Requirements and Obligation of Study Practices}

In analyzing System_D, we deploy a theoretical framework that draws heavily on the philosophy of science developed by Isabelle Stengers (and to a lesser extent Donna Haraway), and more particularly Stengers' reconceptualization of classical, pragmatic ideas. In recent years, this kind of thinking has entered educational discussions (cf. Schildermans et al. 2019a, b). In this article we further elaborate the concept of study practice in relation to the activities System_D deploys. This will allow for bringing the work of Stengers to bear on discussions within philosophy of education.

Based on the work of Stengers, we suggest that study practices roughly develop throughout three moments that together constitute a particular study practice. Firstly, they start from a questioning situation that provides a concrete impetus to start inquiring. Secondly, there is a process of inquiry itself, which can be defined as a specific holding together of requirements and obligations. And lastly, there is the closing of the study practice in which the studiers become capable of response (cf. what Haraway defines as response-ability Haraway 2016). In the following we explain in greater detail these three moments.

First, study practices take place in response to a questioning situation (Stengers 2017). This means that they are a way of engaging with those situations where both scientific expertise and political deliberation fall short of providing a proper solution. Indeed, oftentimes, especially in a world that is increasingly superdiverse, easy solutions based on either scientific knowledge or political convictions, are inappropriate in dealing with such complex situations. Therefore, questioning situations demand processes of study which provoke a specific welding of inquiry and deliberation in order to come to a response.

Second, study practices themselves, elicited by such questioning situations, can be described along two axes, or more precisely, two sets of constraints that are put on the thinking that takes place in the course of these practices (Stengers 2006). Every study practice corresponds to a specific obligation, the first constraint. An obligation is what makes the studiers think and to that extent it is already implicitly present in the questioning 
situation. It allows for making the questioning situation truly problematic. This is because it delays every attempt to provide a quick solution to the questioning situation. It shows itself in the hesitation that studiers feel not to jump hastily to conclusions and to engage longer in the slow process of study.

This process of study is given shape by what the obligation requires of the studiers. In that sense, the requirements, the second axis along which a study practice can be defined, correspond to the obligation, that which is at stake in the study practice (Ibid.). Developing further the work of Stengers $(2006,2010)$, we understand these requirements in terms of the artifices that the studiers are required to think with. An artifice, Stengers (2017) explains, is a way of bringing people, procedures, apparatuses, things, etc. together in order to provoke an event. For study practices, it is the case that thought becomes an impersonal event. Thinking is then not so much what this or that person does, but rather what happens to the ones gathered by the artifice (Schildermans et al. 2019a). As such, analyzing study practices in terms of their requirements necessitates paying attention to concrete ways of doing and acting of studiers, as well as how these ways of doing and acting correspond with what they are obligated by. In other words, whereas the obligations denote what makes studiers hesitate and think, the requirements indicate the activities studiers engage in, in order to become truly responsive to what this obligation requires, or-in other words-how they think. As such, the reciprocal capture between requirements and obligations allows for understanding the singularity of each study practice.

Defining practices in terms of a reciprocal capture between requirements and obligations grants furthermore the possibility to come to a post-critical understanding of what is at stake in the course of the practice (cf. Hodgson et al. 2017). This means that attention is paid to how practices are internally composed as well as how they relate to the problems that had instigated them in the first place. Such problems are a vital ingredient in the constitution of study practices. Adopting such an immanent perspective, however, does not mean to conceive of practices as merely social practices (e.g. Schatzki 1996). This would not do justice to the fact that for every practice something is at stake. Whereas a social-constructivist understanding of practices makes them converge under the interpretivist scheme of social rules, a Stengersian understanding of practice, on the contrary, allows for grasping what is at stake for a specific practice in terms of its requirements and obligations.

Thirdly and lastly, study practices allow for paying close attention to the questioning situation at hand, together with others who are affected by this situation. In this respect, we see a close relationship between the work of Stengers and the learning theory of Dewey (1938): studying a problematic situation implies always a form of gathering around the issue at hand. Only by engaging in an act of collective thinking, the problematic situation can be given the power to make the public affected by it come up with new ways of relating to and dealing with this issue. In other words, the production of such an event will have made studiers become response-able (Haraway 2016): they become capable of responding to the questioning situation in new and unforeseen ways. In that sense, study practices wager on the possibility of "making thought creative of the future" (Whitehead 1929/1958), while resisting the futures that present themselves as more probable. In that sense, they exercise what could be called an "art of the possible" (Stone 2019). The fact that study practices render studiers capable of envisioning futures that are different from the ones that are believed to be inevitable (e.g. the impossibility of solidarity, the failure of multiculturalism, etc.) makes up the specific educational logic of these practices. 


\section{Screening Films Recorded with Smartphones: A Post-critical Analysis}

In this article we focus on a concrete practice, called System_D. It is an arts-based community project with youngsters that gives a response to the challenges of super-diversity in an urban context, by engaging them in making films about Brussels and to show these at a public event, a film festival (Schuermans et al. 2017). System_D operates from one of the 22 community centres in Brussels, called the Piano Factory. A staff team of about 30 employees runs this community centre, which has 200-400 users a day. The Piano Factory deliberately chooses to accommodate very different groups and people under one single roof and in doing so redistributes logistical assistance, public funding and know-how among the various local initiatives and social movements. One of the authors of this article got the opportunity to document this case as part of a research program on 'Diversity and Community Development'. Hence, we had access to reports of the board of directors, magazine articles written by the organizers of System_D, the films themselves and the annual policy reports of the Piano Factory. We interviewed the two youth workers who took the initiative for System_D, next to the person in charge for organizing the film festival in the theatre house, two members of the jury of the film festival and two steering committee members. When this case-study was performed the film festival was already finished, but there was the opportunity to observe the meeting of the 'assemblée generale' (general board) of System_D, where youngsters were invited to discuss the organization of the next film festival (Van Steenberghe et al. 2016).

By paying close attention to the way in which this practice is designed, it is our aim to provide a precise account of study practices, what their proper educational dynamics consist of. Although System_D does not identify itself as a project that involves study, we want to show that what happens here is exactly to be apprehended as a practice of study. Although System_D is also a project aimed at social cohesion and emancipation, it is at the same time something else and more-and it is the singularity of what we have called educational solidarity we want to bring to the fore. At the same time, this practice is also not a mere arts-education project, and that is why we want to call it a study practice.

We hope that our analysis can contribute to highlighting important dimensions that make up this practice (and many others), but that up till now have been disregarded, and we want to develop an appropriate language to describe these dimensions and to give them firm theoretical grounding with the use of educational philosophy. Our approach here is thus affirmative and post-critical (Hodgson et al. 2017): we take the case at face value, trying to underline aspects of it that deserve the attention of educationalists. Our objective is, hence, that the analysis we present here displays System_D in a new way and that it brings to the fore the richness of this project, and the promising possibilities for an educational practice it contains. By combining an investigation of this practice in its concrete doings with philosophical analysis, we hope to unearth its specific educational logic and relevance in current society.

There are, undoubtedly, many interesting cases to be investigated, in and outside formal contexts of education in this regard. But we chose to focus on one, and on this particular case for three reasons. First, System_D explicitly addresses the issue of diversity and solidarity. Youngsters are invited to make a short film and to present it at a festival. Their films are meant as a positive and affirmative response to the challenge of living well together in today's city. Second, the production of these films, the presentation of these films during the festival, and the issuing discussion all entail activities of learning and transformation that we will analyze as forms of study. Third, it is important for us that System_D belongs 
to the non-formal context of youth and community work: one of the claims we want to make is that study practices not only happen at traditional places of learning (schools and universities), but also outside these places (Schuermans et al. 2017). Moreover, we think that living together in the city is in non-formal study practices experienced in a more direct way. Therefore, such study practices seem to allow for investigating and transforming these experiences of living together very intensely.

\section{Representativeness as a Matter of Study}

The questioning situation that the study practice of System_D seems to address is the issue of social exclusion via false or tendentious representations of certain neighborhoods in the media. The superdiverse 'quartiers' of the southern fringes of Brussels are often depicted as an area with many social problems such as poverty, unemployment, and youth criminality (Schuermans et al. 2017). The direct cause for launching System_D are the riots in 2010 on the Betlehem Square. The media coverage of these riots show youngsters pouring out oil on the square, setting fires and throwing rocks at the police. In these media reports there is no attention for the concern of the protesting youngsters, viz. that they demand the police to recognize that they might have committed a mistake in shooting a boy the other day who happened to drive a car belonging to a known criminal. Due to such representations of the 'quartiers' in mainstream media, youngsters felt alienated with regards to their living environment, as they experienced living in these places in an entirely different way. This impression had only become stronger in the wake of the terrorist attacks in Brussels in 2016. Rephrasing this in a Lefebvrian lexicon, there was a gap between the representation of space as conceived by the media and policy actors on the one hand, and the representational spaces of the lived experiences of the youngsters (cf. Ford 2016a).

The study practice of System_D emerged as a way of dealing with this questioning situation of misrepresentation and social exclusion. The practice of study prompted by this problematic situation can be analyzed in terms of its requirements and obligations. What the problematic situation of misrepresentation required from the studiers was that they made images of the 'quartiers' and showed them to the public. Therefore, it is possible to discern two requirements that exist in a reciprocal relationship with the obligation behind the problematic situation to be discussed further on.

The first requirement is that studiers capture their life-world by shooting a real film. This grants the opportunity to pay attention to particularities of the neighborhood they inhabit and for seeing it in a novel way. Only a few instructions are given before the film makers are sent out in the field. First, it is important to stress that the youngsters are addressed as people who are already making images of situations from their lives. Due to the omnipresence of smartphones and social media, the youngsters of the 'quartiers' are always already in the process of creating an archive of images of their neighborhood and what happens there. As such, System_D does not teach the youngsters how to film or to photograph (in fact, they are already able to do this). Rather, the project starts from the material that youngsters were already producing. System_D allows them to gain a more intense attention by means of the call to edit a movie. This means that youngsters have to carefully consider which images to choose, the rhythm of the movie, its storyline, the use of sound, etc., so as to make a film that is attractive for an audience. As one of the steering committee members explains: 
The project wants to avoid that what youngsters produce is seen as a compensation for their societal position. Analyzing System_D as community art entails the risk that the vulnerable position of the participants gets more attention than the artifacts they create (Van Steenberghe et al. 2016).

Moreover, the films do not image faraway times and spaces, but are situated in the 'quartiers'. The call of the film festival does not impose any theme or genre, but specifies that the films must somehow bring the 'spirit of Brussels' to the fore: its urban character and the issues that come with living in the 'quartiers'. In their films, youngsters just show what their hobbies are, or they give an insight into their daily lives, the conversations they have and the jokes they make. They often parody typical interactions between father and son, teacher and pupil, the Islamic community and the police. They display what other people are prone to think and say about them and how people treat them. Some of the films also address social issues, but not necessarily so, e.g. having to make ends meet at the end of every month, living in a house that has walls covered with mildew, and the lack of accessibility to hospitals, to the labour market and to arts centers, but also the many problems that some of them experienced as refugees. ${ }^{2}$

However, merely collecting and editing images into a movie is not enough. What the situation requires is not only to make the movie on their own, but also to show and to discuss it. The second requirement is hence sharing the movie with an audience. This is corollary to the first requirement in that the people in the audience can become studiers themselves and hence become attentive for unforeseen aspects of the life of these youths and the space they inhabit. In this regard, it is, first, important to underline that it is not enough to show the movie in a youth center or a familial setting, but in order to really address the questioning situation of misrepresentation, it is required to show it to a large public. System_D tries to meet this requirement by giving the youngsters the opportunity to screen their movies during a film festival at the Royal Flemish Theater (KVS), a well-established cultural institution in Brussels. In fact, as one of the staff members of this theater observes:

For many youngsters, this is the first time that they leave their neighbourhood .... It is also the first time that their film leaves their neighbourhood and is shared with a wider audience (Ibid.).

The festival attracts a specific mixture of sorts of people which contributes to the public character of the event. As such, the movies are made public in the sense that a variety of people are gathered around the films that the youngsters have made. Moreover, during the festival the film makers have to provide a short oral introduction to their film. Furthermore, after the screening of the film they engage in a discussion and respond to questions posed to them by a jury of professional film makers, but also by the audience. A youth worker contrasts this discussion with how youngsters usually communicate via social media:

They need to be physically present [at the festival] and get questions. They have to answer these themselves, and not with a like or comment (Ibid.).

\footnotetext{
${ }^{2}$ The choice for the medium of film is probably non-accidental and could therefore be considered as an intrinsic element of this requirement. After all, the questioning situation from which the study practice began, was brought about by filmic misrepresentations in the media. Therefore, the medium of film seems to be appropriate to study and contest this situation.
} 
The ensuing discussions can be very much on the edge, as youngsters, members of the jury and participants from the audience bring forward very different opinions about the artistic quality of the films that are shown. Hence,

[t]here is the possibility to address the issue of the codes and the language of cinema and to change ideas about this. The jury plays an important role. The questions which they ask stem from their professional view and their expertise (Ibid.).

Also, issues that speak from these films (e.g. racism, Islamophobia, and sexism) are the object of discussion:

In his project, Nabil [one of the filmmakers] just tried to illuminate both sides. Namely that there are stereotypes both among young people and policemen and that there are rotten fruit on both sides. He did get a hard time during the discussion. Many people from the public criticized the fact that he also had empathy for the position of the police (Ibid.).

What seems to be at stake in the course of the study practice of System_D—and which is hence the central obligation of this practice-is 'representativeness'. Jeff Frank (2013) explains that representativeness is more than merely a matter of producing false or true representations (which always seems to be about veracity). Rather, what seems to be at stake is 'becoming an authority in one's own experience' (cf. Cavell 1981, p. 12). Representativeness, in this context, should be understood as a dual obligation: on the one hand, the commitment by youngsters to document their own life-world, and hence a willingness to stand for what they are experiencing in the 'quartiers'. This means that they bring in their own positionality and make this into an issue that can be experienced by others, i.e. by the audience. Hence, their films are not just entertaining or reality television, they become documentaries. This implies the necessity to accept that the public will scrutinize this authority.

Therefore, and on the other hand, by screening these films in the Royal Flemish Theater they feed into a discussion with a jury and a public. What makes these documentary films into a practice of study is, then, that youngsters 'present themselves as individuals who know something important about the world worth sharing' (Frank 2013, p. 1022). Only because they show their films to the public there is something new and interesting to be experienced-and hence to be studied. Representativeness is about making something present and showing that it is of importance. An image can have a high degree of representativeness in spite of the fact that it is not accurately representative. A documentary that focuses on the extra-ordinary or that exaggerates the situation-which seems to happen in many films of the System_D project—would be a perfect illustration of this. Furthermore, the youngsters must also be willing to see the representativeness of their films as something that a jury and a public have 'a right, even an obligation, to question' (Guzzetti 1996, p. 268 in Frank 2013). Hence, it is not so much about finding right representations of an individual, but about finding out what representativeness as a collective endeavour can be. The format of showing a great variety of films fosters the experience of searching for representativeness.

The study practice of System_D renders the youngsters, as studiers, response-able. In this case, this means that they have become able of responding to the problematic situation of misrepresentation. Indeed, they were put in the position in which they could display the 'quartiers' as they experience them, gather a public around this issue, and hence really make it present. This opens up an experience of potentiality. And this runs counter to a common experience of 'we can't do anything, it has always been this way'. A youth 
worker describes how in the foyer of the Royal Flemish Theater there is often an exuberant atmosphere:

Youngsters start to dance on the tables and don't hide themselves from the gaze of all those who are present in the foyer. It is a way of experiencing freedom or feeling at home which stands in sharp contrast to the mistrust so often experienced in society (Van Steenberghe et al. 2016).

In that sense, this study practice makes thought creative of futures different from the ones that present themselves as obvious or necessary, both individually and collectively. For instance, some youngsters became interested in pursuing a filmmaker career, while others have become more politically engaged in their struggle for representation. The future is also opened in that existing visions of how to give shape to our life in common in the city no longer holds. Instead this question can become the object of discussion while omitting the risks of identity politics.

\section{Conclusion: Film as an Artifice for Learning Anew}

The objective of this article has been double. On the one hand, our interest was in the concept of study practices and how this concept could be developed in a more substantial way based on an analysis of a concrete practice. On the other hand, we were particularly interested in aspects of solidarity present in the course of study practices, and how study practices henceforth allow for understanding solidarity in the super-diverse city in a new way, which markedly differs from the standard optimistic and pessimistic approaches we described in the introduction. In the first part of this concluding section, we will focus on System_D as a study practice and articulate the educational processes at play here. Thereafter, we will explain why System_D allows for a kind of solidarity that is not future or past-oriented, but rather situated in this actual practice, and how solidarity can be understood as properly educational solidarity.

In the definition of study we gave at the beginning of this article, we have emphasized that study has a strong collective dimension and that it enacts an occasion for politics (cf. Ford 2017). At the same time, we have explained our interest in the possibility of reclaiming of the notion of learning as a process of collective, indeterminate transformation that might allow to shed new light on the question of solidarity in superdiversity. Turning to System_D, what seems to be at stake is that young people belonging to minority groups come up with alternative filmic presentations of their neighborhoods. By becoming collectively affected by the obligation of representativeness (i.e. 'becoming an authority in one's own experience'), they learn anew (Schildermans et al. 2019a). Learning anew denotes, then, transformative processes in which a matter of study, viz. the different short films, engages a collective in a discussion on their shared life world and renders them responseable, i.e. capable of responding to the questioning situation of misrepresentation (Ibid.). As such, the study practice of System_D enacts a reciprocal capture between the requirements of making and showing movies on the one hand, and the obligation of representativeness on the other hand. Consequently, this study practice renders the youngsters that live in the 'quartiers' capable of responding to the often alienating representations of their neighborhoods in the media.

Now, it is interesting to observe that System_D, as a study practice, finds its origin in a political problem, but that in addressing this problem the practice itself never becomes a 
political practice itself. A political practice, as we define it, is about formulating concrete demands, undertaking action to make these demands heard and/or trying to influence policies. $^{3}$ This is not to say that study practices cannot have profound political consequences (which is the goal of the youth workers involved in the practice, see Schuermans et al. 2017). But, our analysis suggests that starting to pay attention to one's life world and learning to see anew, but also carefully editing films and discussing the content and quality of one's work with a jury and a public are all thoroughly educational. The movies themselves can therefore be considered as artifices that provoke study. This is because their efficacy lies not so much in judging existing representations right or wrong, or in giving a voice to excluded groups of people (which are direct political objectives). What is at stake is raising the question how to live together in a super-diverse city. Or, more exactly put, this question is turned into a matter of study. Living together becomes an educational (instead of merely a political) issue: the youngsters that live in the 'quartiers' can take distance, they can hesitate and suspend the time of direct action, and hence they can start thinking outside of the confines of already established accounts of the problem (of representation) they are faced with. They (but also the audience) can relate to their situation in new and unforeseeable ways. This is clear, we argue, from the way in which the 'classical' problem of representation is turned into an issue of representativeness. As such, these films also constitute a public in the Deweyan sense (Dewey 2016). This is to say that both the youngsters and the audience get involved in making up their minds about the issue of representativeness in ways that might run counter to already set expectations.

We want to argue, moreover, that this analysis of filmmaking in terms of study practices also allows for developing a new approach to the issue of solidarity. As we explained, solidarity today is often seen as an ideal of the past we better put aside, or as a desirable future objective to be reached through the deployment of educational means. What our analysis of System_D suggests is that a particular form of solidarity exists, not as a goal which justifies the meaningfulness of this practice, but as something that arises and that can be experienced while studying together. People are not only coming together around an issue and thus constitute a community. They also study together: they are attentively involved in the making of an artistic object (which puts particular demands on these studiers) and in collective discussion and thought (beyond the confines of that what is given and taken for granted).

In that precise sense, solidarity seems to be an immanent quality of study practices. This also implies that the case of System_D presents us with a form of solidarity that is not political, economic or cultural (e.g. a commonality resulting from a shared struggle, the redistribution of scarce resources, interdependency, or a uniformity in values and interests people hold). By turning an issue into a matter of attentive and collective study, they become able to respond to a situation and to imagine the world anew in a thoughtful way. This ensures a form of togetherness and belonging that does not result in a group identity, so much as in a collective stammering with regard to the problematic situation.

In sum, educational solidarity comes forward as a togetherness forged through experiences of being engaged in a common investigation into a thing that appears as worthy of such an effort. It manifests itself in and through a common orientation and devotion to a thing of study. And it is precisely the attentiveness to these films that brings about an

\footnotetext{
${ }^{3}$ Evidently, if one would define politics in a different way, e.g. as changing the structures of our common way of perceiving the world (Rancière 1999), this would imply an altogether different analysis of how study practices and politics relate.
} 
important educational event in the life of the youngsters inhabiting the 'quartiers' and also to the audience that comes to watch these films, namely: they come to experience that the issue of representativeness is an important question that makes them think. Youngsters and audience experience then in a most concrete manner that there is no necessity in how life in common is taking place now in Brussels. And as we have argued in this article making films and discussing about these films are activities that themselves constitute this experience of indeterminate, collective transformation.

Acknowledgements Open access funding provided by University of Vienna.

Open Access This article is licensed under a Creative Commons Attribution 4.0 International License, which permits use, sharing, adaptation, distribution and reproduction in any medium or format, as long as you give appropriate credit to the original author(s) and the source, provide a link to the Creative Commons licence, and indicate if changes were made. The images or other third party material in this article are included in the article's Creative Commons licence, unless indicated otherwise in a credit line to the material. If material is not included in the article's Creative Commons licence and your intended use is not permitted by statutory regulation or exceeds the permitted use, you will need to obtain permission directly from the copyright holder. To view a copy of this licence, visit http://creativecommons.org/licenses/by/4.0/.

\section{References}

Cantle, T. 2012. Interculturalism: For the Era of globalisation, cohesion and diversity. Political Insight 3 : $38-41$.

Cavell, S. 1981. Pursuits of happiness: The hollywood comedy of remarriage. Cambridge, MA: Harvard University Press.

Dewey, J. 1938. Experience \& education. New York (NY): Kappa Delta Pi.

Dewey, J. 2016. The public and its problems. An essay in political inquiry. Athens: Ohio University Press.

European Commission (2018). Solidarity in Europe-Alive and Active. https://ec.europa.eu/research/socia 1-sciences/pdf/policy_reviews/solidarity_in_europe.pdf.

Ford, D. 2016a. A pedagogy for space: Teaching, learning, and studying in the Baltimore Rebellion. Policy Futures in Education 14 (2): 176-193.

Ford, D. 2016b. Communist study: Education for the commons. Lanham (MD): Lexington Books.

Ford, D. 2017. Studying like a communist: Affect, the party, and the educational limits to capitalism. Educational Philosophy and Theory 49 (5): 452-461.

Frank, J. 2013. The claims of documentary: Expanding the educational significance of documentary film. Educational Philosophy and Theory 45 (10): 1018-1027.

Guzzetti, A. 1996. Notes on representation and the nonfiction film. New Literary History 27 (2): 263-270.

Haraway, D. 2016. Staying with the trouble. Making kin in the Chthulucene. Durham, NC: Duke University Press.

Hodgson, N., J. Vlieghe, and P. Zamojski. 2017. Manifesto for a post-critical pedagogy. Goleta (CA): Punctum Books.

Lewis, T.E. 2014. The fundamental ontology of study. Educational Theory 64 (2): 163-178.

Lewis, T. 2015. On study: Giorgio agamben and educational potentiality. London: Routledge.

Mollenhauer, K. (2013). Forgotten connections: On culture and upbringing (N. Friesen, Trans.). London: Routledge.

Moten, F., and S. Harney. 2013. The undercommons. Fugitive planning and black story. London: Minor Compositions.

Putnam, R. 2000. Bowling alone: The collapse and revival of American community. New York: Simon \& Schuster.

Rancière, J. (1999). Dis-agreement. politics and philosophy (J. Rose, Trans.). Minneapolis, MN: University of Minnesota Press.

Ruitenberg, C. (ed.). 2017. Reconceptualizing study in educational discourse and practice. London: Routledge.

Schatzki, T. 1996. Social practices. A Wittgensteinian approach to human activity and the social. Cambridge: Cambridge University Press. 
Schildermans, H., M. Simons, and J. Masschelein (2019a). Making a university. Introductory notes on an ecology of study practices. KU Leuven (Unpublished doctoral dissertation).

Schildermans, H., M. Simons, and J. Masschelein. 2019b. From ruins to response-ability: Making a university in a Palestinian refugee camp. In Post-critical perspectives on higher education. Articulating the educational in the university, ed. N. Hodgson, J. Vlieghe, and P. Zamojski. Rotterdam: Springer. (in press).

Schuermans, N., J. Vandenabeele, S. Oosterlynck, M. Jans, and D. Holemans (eds.). 2017. Soldidariteit in superdiversiteit. Handvatten voor concrete actie. Leuven: Acco.

Simons, M., and J. Masschelein. 2009. Towards the Idea of a World University. Interchange 40 (1): 1-2.

Stengers, I. 2006. La Vierge et le neutrino. Scientifiques dans la tourmente [The Virgin and the neutrino. Scientists in turmoil]. Paris: La Découverte.

Stengers, I. (2010). Cosmopolitics I (R. Bononno, Trans.). Minneapolis, MN: The University of Minnesota Press.

Stengers, I. 2017. Civiliser la modernité? Whitehead et les ruminations du sens commun [Civilizing modernity? Whitehead and the ruminations of common sense]. Dijon: Les Presses du Réel.

Stone, L. 2019. From ethics to ethics: Combatting dangers to democracy. Ethics and Education 14 (2): 143-156.

Van Steenberghe, T., J. De Haene, R. Steel, J. Vandenabeele, and G. Verschelden (2016) Rapport retrospectieve case study: System_D. Solidariteit via een artistiek antwoord op een politiek probleem. Internal report (DieGem).

Vertovic, S. 2007. Super-diversity and its implications. Ethnic and Racial Studies 30 (6): 1024-1054.

Whitehead, A. N. (1929/1958). The function of reason. Boston, MA: Beacon Press.

Zhao, W. 2019. Daoist onto-un-learning as a radical form of study: Re-imagining study and learning from an Eastern perspective. Studies in Philosophy and Education 38: 261-273.

Publisher's Note Springer Nature remains neutral with regard to jurisdictional claims in published maps and institutional affiliations. 